\title{
Journey of Goranis' from Bogomils’ to Islam
}

\author{
Mr. Sc. QAFLESHI, MUHARREM ${ }^{1}$ \\ ${ }^{1}$ Prishtina University, Departament of History \\ Correspondence: Prishtina University, Departament of History. \\ Received:February 1, 2018 Accepted:February 17, 2018 Online Published: May 15, 2018 \\ doi:10.5539/res.v10n2p190 URL: https://doi.org/10.5539/res.v10n2p190
}

\begin{abstract}
The Gora region today is located in the border triangle between Albania, Kosovo and Macedonia. For several decades, the identity of this population isunder dispute. There have been numerous attempts by Serbs, Bulgarians and Macedonians, and they continue today, to represent the population of this region as having Serbian, Bulgarian or Macedonian origin. Based on the history of this region and a number of elements of culture, characteristic houses, national dresses, songs, dances, habits and customs that are preserved among the residents, it is unclear because the language is a mixture of Slavic languages while the habits and customs are very close to those of Albanians. One of the versions of ethnic identity of Goranis'is the connection with Torbeshis'as the last remnants of Bogomils', a heretical religious movement. Same as Opojans' also the Goranis' today belong entirely to the Muslim religious group. There are numerous evidences for cult objects such as mosques and shrines built earlier than the expansion of the Ottoman Empire in our region. With the expansion of Ottoman Empire in the Albanian lands, also the population of Opoja and Gora embraced Islam, today this population is entirely Muslim, and in each village, there are mosques of modern architecture and very beautiful minarets.
\end{abstract}

Keywords: Gora, Ottoman Empire, Islam, Torbeshis', Bogomils'

\section{Gora and Goranis' as Last Torbeshis' of Bogumilism in the Balkans}

Gora is one of the geographical and ethnographic areas of Kosovo, which comprises the southern edge of Kosova, which with a part of its territory stretches further into Albania and Macedonia. It is a mountainous area of Sharri mountain which stretches $^{1}$ to the east of Kukës, to the north of Xërxe Mountain (1347 m), to the east of Kaçina Gllava (2407 m), to the south of Gemitash (2204 m), to the southwest of Kallabak (2174 m), to the west of Gjallica (2886 m) and to the northwest ofKoretnik mountain. It should be noted that these boundaries couldn't be considered as fully precise however they mark its natural and traditional boundary. It borders to the southwest, west and northwest with Luma, to the northeast and east with Opoja and to the southeast with Tetova. ${ }^{2}$ Gora Region is comprised of the following villages: Baçkë, Brod, Dikanci, Dragash (older name Krakojshte), Glloboçicë, Kukolan, Lubovishtë, Mlikë, Orçushë, Radesh, Rapçë, Restelicë, Vranisht e Zlipotok. Administratively all these villages belong the Municipality of Dragash. ${ }^{3}$ On the other side, villages: Borje, Cërnalevë, Kosharisht, Orçikël, Orgosht, Oresh, Pakish, Zapod, e Shishtavec administratively belong to the Kukës area. Jelovljani and Urviqi are two villages that are located within the Republic of Macedonia. ${ }^{4}$ As it can be seen from the earlier traces of the past, almost all the today's villages are located in the same place like the old ones. This clearly shows that on these locations have been present the best geographical conditions for establishing permanent settlements. At all times, the locations of settlements were determined by the main living conditions such as pastures, water, agriculture land and road connections between mountains and settlements. Besides the location of settlements in some villages is noted also the influence of strategic importance. It is understood that for the establishment of settlements not always these conditions had to be met in full. To establish a settlement it was sufficient to have pastures, water and protection from

\footnotetext{
${ }^{1}$ Qafleshi, Muharrem, (2014), Goranët dhe identiteti i tyre, Gjurmime albanologjike, nr. 43/2014,Prishtinë, pg. 25; Instituti Albanologjik - Prishtinë.

${ }^{2}$ Dokle, Nazif, (1999), Jehona Homerike në Kukës, Prizren, pg. 50.

${ }^{3}$ Gashi, Skender, (2011), Gora dhe “boshnjakët” - nërkamëz tjetër për Kosovën, revista "Sharri”, Dragash.

${ }^{4}$ Qafleshi, Muharrem, (2014), Goranët dhe identiteti i tyre, Gjurmime albanologjike, nr. 43/2014,Prishtinë; Instituti
}

Albanologjik - Prishtinë, pg. 265. 
wind, in Gora for example. ${ }^{5}$ Since 1348 when we find it initially in the written documents, in the following centuries and until today, name Gora is unchanged. This word belongs to the Slavic fund and its meaning is Mountain. ${ }^{6}$ This happened when Czar Dusan passed the village Brod of Gora with these boundaries to the monastery of Saint Archangel in Prizren in $1348 .{ }^{7}$ Hence, the half of 14th century finds Gora villages consolidated with some of them being properties of monasteries.

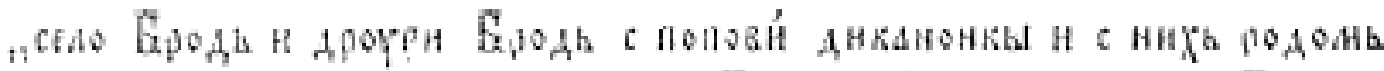

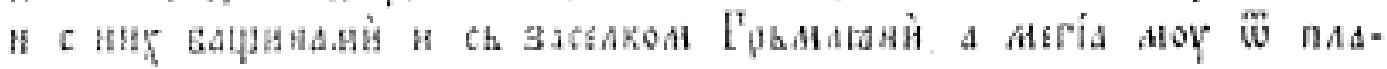

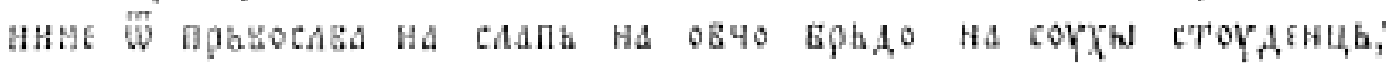

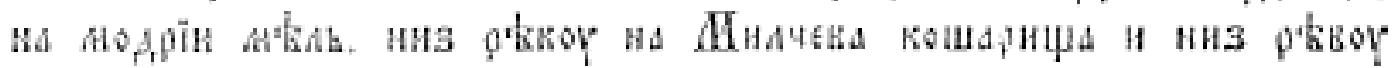

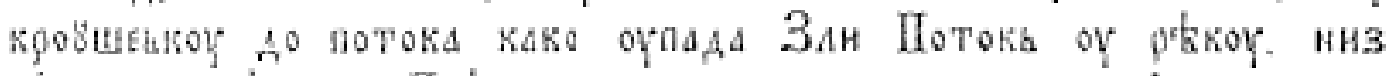

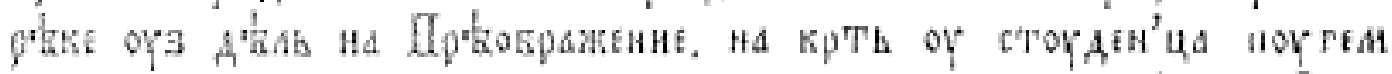

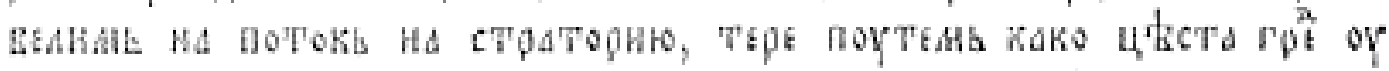

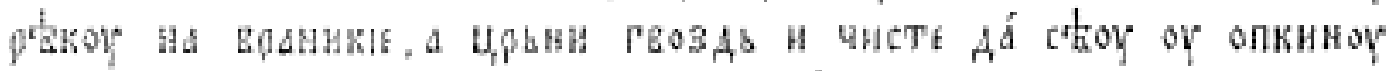

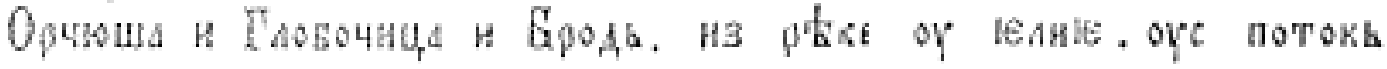

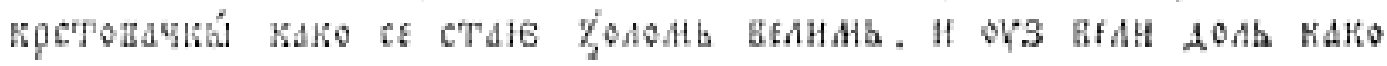

\section{Факсимил 1. Хрисовуьа иара Стефана Дуиана, Гласник Друитва србске словесности, ХV, Београд, 1862, стр. 181-182.}

According to Turkish registrations during the years 1571, 1591, Gora Region consisted of 38 villages. Although anthroponymy reports of these registers do not reveal exactly the truth about the ethnicity, they speak of Slavic ethnicity of some villages and for Albanian-Slavic coexistence in some other villages, along with the mutual assimilation process. In 1571 in Gora 1355 heads of families were holding pure Slavic anthroponomy, 34 Albanian anthroponomy and 134 mixed Albanian-Slavic anthroponomy ${ }^{8}$. Due to the spoken Slavic language of Goranis' from Gora, different Balkan countries attempted to appropriate this ethnic group, for example, there are Serbian historians and linguists who treat the Goranis' as Serbs, Macedonian historians and linguists call them Islamized Macedonians whereas the Bulgarian state names them as Bulgarians. These attempts are unrelated to the movement of Goranis' that is this does not happen because the Goranis' originate from these countries or belong to their ethnicity, but this is due to their spoken language.

The embedded ideology in the generations of Serbian politicians, which as a founding principle has the occupation of the others' lands, be it with the price of genocide, along with the devotional projecting ideology - Serbian Academy of Sciences, had its spiritual inspiration - the Serbian Orthodox Church ${ }^{9}$. Due to the spoken Slavic language of the Gorani community, Serbian Government during the years 1994-1995 engaged the Serbian Academy of Sciences and Arts (SASA), or more precisely the so called "Sector for Studies related to the Kosovo and Metohija" and the Geographical Institute "Jovan Cvijic" within this academy ${ }^{10}$. Around 20 science institutions with approximately 93 Serbian scientists belonging to different fields of study, participated in the study of the ethnicity of Gorani', as an "old Serbian population" ${ }^{11}$. This academy, with all those institutions and scientists published three printed volumes by SASA related to Kosovo and

\footnotetext{
${ }^{5}$ Lutovac, Milislav, (1955), Gora i Opolje - antropogeografska proučavanja, odeljenje druśtvenih nuka SAN, Beograd, pg. 51.

${ }^{6}$ Dokle, Nazif, (1999), Jehona Homerike në Kukës, Prizren, pg. 50.

${ }^{7}$ Hristovula, 1862, pg. 181-182.

${ }^{8}$ Dokle, Nazif, (1999), Jehona Homerike në Kukës, Prizren, pg. 53, 54.

${ }^{9}$ Matoshi, Hysen, (2012), Hapësira etnike e kulturore shqiptare dhe Kisha Ortodokse Serbe, Shkup, Prishtinë, Tiranë, pg. 7.

${ }^{10}$ Hahimi, Bedri, (2012), Goranët, Prishtinë, pg. 102.

${ }^{11}$ Qafleshi, Muharrem, (2011), Opoja dhe Gora ndër shekuj, Prishtinë, 14; Instituti Albanologjik, Prishtinë.
} 
with special emphasis to the regions of Gora, Sredska and Opoja ${ }^{12}$. All three volumes were titled "Zhupas' of Sharri Mountains - Gora, Opoja and Sredska” (in Serbian, „Šarplaninske Župe - Gora, Opolje i Sredska“) ${ }^{13}$.All these Serbian academics and professors in cooperation with five Goranis' from the Gora region, Harun Hasani, Behadin Ahmetovic, Orhan Dragash, Vait Ibro and Mesip Dalifi, on these three books conclude that Goranis' have Serbian origin, who according to them up until a century ago were of orthodox confession. Hence, these Serbian science and political institutions attempted to prove that since their arrival in Balkans during the $6^{\text {th }}$ century, south Slavs have ruled the Kosovo region and that Albanians arrived later, by the end of $17^{\text {th }}$ century and mostly during the $18^{\text {th }}$ century ${ }^{14}$. Serbian authors think that also Albanians from the Opoja region during the $17^{\text {th }}$ and $18^{\text {th }}$ century were converted from Slav's into Albanians ${ }^{15}$. In this way, instead of engaging historians to research the ethnicity of Goranis', it was made even more unclear in part due to the contribution of the politicians living and operating in Serbia along with the scientist of the regional countries at the service of the Slavic politics (Serbia, Macedonia and Bulgaria).

\section{Torbeshi's as the Last Remnants of Bogomil's}

Bogomil's represent one of the medieval sects, the massive heretical movement or the so-called New Heresy ${ }^{16}$. For the first time it was spread in Bulgaria, which for a long time was shaking between the Rome and Byzantine Empire, and the new religion spread fast. This religion's followers known as Bogomils' (in Slavic the God's Beloved), sent their missionaries all over the place ${ }^{17}$, that is throughout Balkans, Byzantine Empire, Europe and Asia Minor and for nearly five centuries had a strong impact in the philosophy, religion, social science, politics, culture and economy of these regions ${ }^{18}$. This movement, which had started during the middle of $10^{\text {th }}$ century, during the years $1018-1118$, had faced an unprecedented persecution associated with the displacement of this population in different directions. In the Balkans, these heretics were called Babuns, Torbeshis', Patarins' or Kudugjers'. The nickname Torbesh (beggar) used by the Orthodox Church in contempt of heretics, as those who rose against the beggary, followed them up until this day ${ }^{19}$. Mary Edith Durham cited by Nazif Dokle, speaking of the role of heretics, says: Manichaeism had spread its roots strongly in the Sinisi of Balkans since the times of Justinian and now is covered with a form of Christianity. In the Samosata of Asia Minor emerged a new sect known as Pavlikans'. They united the Manichaeism with a special reference for the sermons of Saint Paul. Persecuted by the Christians, they united with Muslims and organized revolts that disturbed a major part of Asia Minor. The Emperor Kopronymus (741), with the intention to weaken them, sent a majority of them to Thrace to serve as border guards. Gjon Zimicesi (969) displaced another part of them towards the Balkan's valleys. Since this time their doctrines started to spread fast ${ }^{20}$. Bogomilism was defined first of all as an expression of discontent of oppressed villages against the ruling class and official church ${ }^{21}$. For the Bogomils' were used other names that also had massive expansion and usage. In the Macedonian regions, and in the Serbian lands, Bogomils' were called "Babuns", "Kudugjers"" and "Torbeshis" 22 . In Bosnia they were called by the locals as "Christians" and by the foreigners as "Patarens"23. Dimitar Angelov has concluded that Torbeshis' are the last successors of Macedonian Bogomils ${ }^{24}$. After we explored all the opinions known to us concerning the origin of the name Torbesh, the most reliable one seems to us to be that which relates it to the Bogomil movement ${ }^{25}$.

The journey of this name shows us that Torbeshis', forced to flee from their country, escaped in three directions: First

${ }^{12}$ Halimi, Goranët, pg. 103.

${ }^{13}$ Halimi, Goranët, pg.103.

${ }^{14}$ Vickers, Miranda, (2004), Midis serbëve dhe shqiptarëve, Tiranë, pg. 24.

${ }^{15}$ Malcolm Noel, (2001), Kosova - një histori e shkurtër, Prishtinë, pg. 205.

${ }^{16}$ Shuteriq, Dhimitër, (1980), Shënime mbi herezinë në Shqipëri, Tiranë, pg. 199; Studime historike 2" - Tiranë.

${ }^{17}$ Durham, Edith, (1927), Bosnja e Hercegovina, “Njëzet vjet ngatërresa ballkanike”, Tiranë, pg. 148.

${ }^{18}$ Dokle, Nazif, (2009),Bogomilizmi dhe etnogjeneza e torbeshëve të Gorës së Kukësit, Tiranë, pg. 9.

${ }^{19}$ Dokle, Nazif, (1995), Glas Gore, nr. 7, Dragash, pg.4.

${ }^{20}$ Durham, Edith, (1927), Bosnja e Hercegovina, “Njëzet vjet ngatërresa ballkanike”, Tiranë, pg.136.

${ }^{21}$ Dokle, Nazif, (2009),Bogomilizmi dhe etnogjeneza e torbeshëve të Gorës së Kukësit, Tiranë, pg. 13.

${ }^{22}$ Osi, Maliq, (1996), Prizren drevni grad, utvrgjenja i njegova najneposrednija sella Jabllanica i Pousko, Prizren, pg.

142-145.

${ }^{23}$ Panov, Branko, (1985), "Srednovekovna Makedonija”, Skopje, pg. 269.

${ }^{24}$ Angelov,Dimitër, (1962), "Bogomilstvoto v'Blgaria, Sofja, pg.150.

${ }^{25}$ Dokle, Nazif, (1999), Jehona Homerike në Kukës, Prizren, pg. 60. 
direction was through Shkup - Rekë - Gora - Gjakova (as patronim) - Bosnia, where Bogomils ended their journey. Second direction was Shkup - Manastir - Tërbaç (Gollobërdë) - Tërbaç (Vlorë) - Napoli. The third direction was from Macedonia to Asia Minor. ${ }^{26}$ In the first direction Torbeshis' survived and established compact settlements whereas in other directions they left behind only the echo of their tragic end in the fire of European hermeticism. Due to their hatred for the Orthodox Church preferred the Catholic Church, and upon the expansion of the Ottoman Empire in these territories it did not take very long until they embraced Islam. Their Opoja and Luma neighbors call the Goranis' as Goran, Torbesh or Poturs'. Their language is called Nashke or Sheknisht (Shkije is a humiliating name given by Albanians to Serbs). They call themselvesGorani, Nashinci and their language Nashinski. For the Goranis' origin and the ethnic background of Gora there is not much information. We may say that history is silent about this problem. On the other side, the Albanian science has been silent almost completely. Even beyond the border, nothing big has been said. ${ }^{27}$ (There has been no case when the Gorani national conscience was determined, they do not call themselves either Serbs, Bulgarians, Macedonians or Albanians, only Goranis' or Bosnians'. That part of Gorani population that calls themselves as Goranis' believe that their ethnicity is a Slavic one. The majority part of this community calls themselves as Bosnians' - Muslims who identify their ethnicity with religion. This means that in the same way that Serbs, Bulgarians, Montenegrins and Macedonias are united around the Orthodox religion, the Goranis' and Bosnians' were united around Islam. To enlighten the ethnic genesis of Goranis', we will stop at the name "Torbesh" as one of the names used to call the last remnants of Bogomils'. In this study, we will review the connection between Goranis with Bogomils'-Torbeshis'.

The Gorani researcher Nazif Dokle in his book "Bogomilism and ethnic genesis of Gora and Kukes Torbeshis", writes about the etymology of the name "torbesh" which is used to call the residents of this region and has different opinions. The majority of them have the opinion that the name "torbesh" is related to the Bogomil movement and that they are the last remnants of Macedonian Bogomils". ${ }^{28}$ Dokle in this book dedicated to the ethnic genesis of Torbeshis' of Gora gives the following evidence: "The clear evidences of Bogomilism in Gora are the names "babun", "kudugjeri", "funda" and "mano" which were used in the middle ages along with the name Torbesh to identify the heretic Bogomils" and which are still found here or around this region. ${ }^{29}$ According to the other Bulgarian researcher Jordan Ivanov: "To the Bogomil church belonged also Torbeshis' after which they embraced Islam. They now live in Tikvesh, Kercova, Diber, Shkup and in the Gora region. ${ }^{30}$ According to the Gorani researcher Nazif Dokle, the name "torbesh" is to be sought in the centuries as a very old name of Slavic population. This author further continues to say that the others relate the Bogomil movement and the Torbeshis' are considered to be the last remnants of this movement. ${ }^{31}$ Jovan Cvijic in his book "Balkansko poluostrvo, juzno slovenske zemlje" writes: "Goranis' have similarities with the Mijakis (Torbeshis') of Reka e Vogel, left branch of Radika". ${ }^{32}$ The bridge located between the region of Gora and Radika called "The Torbeshi Bridge" may enforce the idea that Goranis 'may have ethnic relations with the Mijakis". ${ }^{33}$ It is very probable that Bogomil Torbeshis' while escaping the violence exercised by the Church and Slavic countries of the Balkans have settled with permanent residences in these mountainous regions with good conditions for development of farming, having in mind that Goranis' are good farmers, and they have derived their named from old Slavic name Gora based on the hilly or mountainous configuration of this region and which name itself means Mountain. In a way, Goranis' depending on which countries stretched their powers in these regions embraced their beliefs, during the byzantine-bulgarian-serbian time they embraced Orthodox Christianity and in the $16^{\text {th }}$ century when the Ottoman Empire stretched in these territories they embraced Islam.

\section{Embracing of Islam by Goranis' During the Ottoman Empire}

The inscription of the Mosque in Mlike village shows that Islamin this region was present since the 13th century ${ }^{34}$ or more precisely since before the arrival of Ottomans in Prizren (1459). Based on the research data from historians it is suggested that this mosque was built by few ArabMuslim families displaced from Syria and it does not belong to Ottoman

\footnotetext{
${ }^{26}$ Dokle, (1999), Jehona Homerike në Kukës, pg. 61.

${ }^{27}$ Dokle, (1999), Jehona Homerike në Kukës, pg. 51.

${ }^{28}$ Dokle, Nazif, (2009),Bogomilizmi dhe etnogjeneza e torbeshëve të Gorës së Kukësit, Tiranë, pg. 79.

${ }^{29}$ Ibid, pg.88.

${ }^{30}$ Ivanov, Joradan, (1925), Bogomilski knjigi i legendi, Sofia, pg. 36.

${ }^{31}$ Dokle, Nazif, (1999), Jehona Homerike në Kukës, Prizren, pg. 59.

${ }^{32}$ Cviç, Jovan, (1969), Ballkansko poluostrvo i juzne - slovenske zemlje, Beograd, pg. 491.

${ }^{33}$ Melqi, Hajriz, (1994), Opoja dhe Gora, Prishtinë, pg. 51.

${ }^{34}$ Monography of the south Kosovo region, An EU funded project managed by the European Union Office in KosovëImplemented by: Arbeiter - Samariter - Bund ASB, Prizren 2012, pg. 57.
} 
constructions. In the meantime, even nowadays the neighborhood where the mosque is located is called Halepovci, while the city of Aleppo at that time was within the Bejlik of the aristocratic family of Dylkadërogullari. ${ }^{35}$ According to some Opoja historians the inscription found in the Mlike mosque proves that this mosque is the oldest religious building in Kosova and in Albania in general and shows that Muslim missionaries in Gora arrived in 1353, which dates is much earlier date than the one when in Gora and Opoja was spread the Islamic faith. ${ }^{36}$ This inscription translated by Nehat Krasniqi, an expert of ottoman language, has this meaning: "This honored mosque was reconstructed, through allowed (hallall) wealth, by Ahmed Aga, may God show mercy upon him in the year $1238 \mathrm{H} / 1822$. Initially (an unreadable word may be was a church in $688 \mathrm{H} / 1289$ /"'.

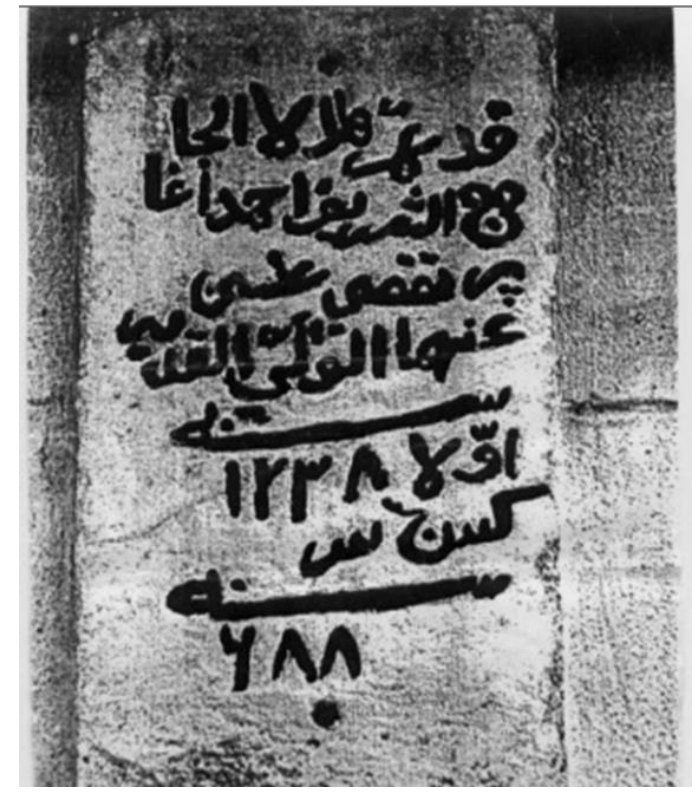

Also there are traces of Muslim missionary Sari Saltuk such as the Pllava Shrine.

After breaking the resistance of the Balkan nations, Ottoman Turks in the first years of the $16^{\text {th }}$ century spread through the larges parts of Albania. ${ }^{37}$ This also took place in the regions of Opoja and Gora, in the ancient Dardania. This lead to the embrace of Islam.

Slavic authors Jastrebov and Lutovac about the conversion of Goranis' and Opojanis' into the Islam religion give anti scientific thesis such as their following incorrect conclusions: Jastrebov believes that residents of Opoja during the $17^{\text {th }}$ and $18^{\text {th }}$ century were converted from Serbs into Albanians. ${ }^{38}$ On the other side, according to Lutovac the Ottoman Empire forcibly converted the population of Opoja and Gora, but while the Gora population embraced only Islam and saved their old and pure Serbian language, the Opoja population embraced Islam and also converted into Albanians. ${ }^{3}$

Upon the embrace of Islam, also the tradition of Islamic religious education was developed in Kosova, which is older than six centuries. This activity started from the early years of spreading of Ottoman power in this part of Balkans, where along with the process of embracing the religion of Islam in Kosova, started the process of spreading of Islamic civilization and as a component of this also the Religious-Islamic education. As an outcome of this, in several parts of Kosova, somewhere more and somewhere less, depending on their strategic and economical position, started to be established institutions of religious and educational character such as mosques, madrassas, libraries, etc which were maintained through the system of Waqf. These institutions played a large and positive role within the population, in their wellbeing and religious formation. The role of mosques as an educational and religious institution was and remained huge because from there began the education in these territories. In the mosques', besides completing the religious duties, the Muslims had the possibility to be educated through waz and wazaifs, because these personalities in the largest centers of Kosova were also

\footnotetext{
${ }^{35}$ Monography of the south Kosovo region, pg.57.

${ }^{36}$ Hajriz Meleqi, Gora andGoranis', manuscript.

${ }^{37}$ http://www.letersia.fajtori.com/Historia/Timari në shekullin XVI.

${ }^{38}$ Jastrebov, Ivan, (1995), Stara Serbija, Priština, pg. 57.

${ }^{39}$ Lutovac, Milisav, (1955), Gora i Opolje, Antropogeografska istraživanja, Srpski Etnografski zbornik, knj 69, Beograd, pg. 51 .
} 
among the most educated personalities. Besides mosques a great role in the education aspect was played by the madrassas. Madrassa as an educational institution was initially born within the Arabs, which was then taken by Seljuq Turks and from them by Ottomans who then brought it to Balkans, that is in Kosova as well. ${ }^{40}$

Based on the historical data, construction of Mosques started after the "Kosovo Battle" of 1389. Xhamia e Çarshisë in Prishtina was built in 1440 . This activity was further expanded especially during the $16^{\text {th }}$ century and in the first part of $17^{\text {th }}$ century, when gradually the Islamic population began to take over, especially through the cities. ${ }^{41}$ In the same way, also in the territories of Opoja and Gora the religion of Islam started to spread quickly, and according to the evidence of cult monuments, it turns out that the mosque of Shajne village was older than Xhamia e Çarshisë in Prishtina, as it was build in $1413{ }^{42}$ In the so called Islamic defters, besides the data about the social and economical situation of Opoja and Gora, a special emphasis was given to the data about the registration of population. According to this data, majority of population in Opoja, in 1571 was Islamized and as a result its anthroponomy belonged to the sphere of Islamic anthroponomy. Now it consisted of 84 families and 14 Christian bachelors, 233 married Muslim families with land. There were also 61 married families without land (bennak) and 75 Muslim bachelors. In Opoja and Gora, in these two regions, the Islamic religion was spread since the $16^{\text {th }}$ century, and since that time, in these territories of Sharri Mountains, were preserved a considerable number of architectonic monuments of Islamic heritage such as: mosques, shrines, tombstone inscriptions, water fountains and sarays. Monuments of sacral and profane architecture contain elements of oriental architecture and especially of Ottoman architecture. A true treasure of material inheritance represent the Islamic buildings built by Kukli Beg such as the Mosque of Kukli Beg in Bresana village (which is under the protection of the Institute of Culture Monuments of Kosova), the hamam, the shrine and the tombs of his family as well as the Saray and the water fountain near the Saray of Kukli Beg, which until today preserve the rich urban-oriental integrality, surely with some changes, because time by time some repairs were made. There is also the Namasgja in Buzes village, the Plava Shrine which belongs to the time of Sari Saltuk. In this way, Goranis call themselves as Bosnians-Muslims also from the ethnic and religious point of view.

\section{References}

Angelov, D. (1962). Bogomilstvoto v'Blgaria, Sofja.

Cviç, J. (1969). Ballkansko poluostrvo i juzne - slovenske zemlje, Beograd.

Dokle, N.(1995). Glas Gore, nr. 7, Dragash.

Dokle, N. (1999). Jehona Homerike në Kukës, Prizren.

Dokle, N. (2009). Bogomilizmi dhe etnogjeneza e torbeshëve të Gorës së Kukësit, Tiranë.

Durham, E. (1927). Bosnja e Hercegovina, "Njëzet vjet ngatërresa ballkanike", Tiranë.

Dy, D. (1999). Etimologiia e toponimeve, Opojë, Gorë, Torbesh dhe Bellobard, Kukës.

Gashi, S. (2011). Gora dhe "boshnjakët” - nërkamëz tjetër për Kosovën, revista "Sharri”, Dragash.

Hakimi, B. G. (2012). Prishtinë.

Hristovula cara, S. D. (1862). Beograd.

Ivanov, J. (1925). Bogomilski knjigi i legendi, Sofia.

Jastrebov, I. (1995). Stara Serbija, Priština.

Lutovac, M. (1955). Gora i Opolje - antropogeografska proučavanja, odeljenje druśtvenih nuka SAN, Beograd.

Malcolm N. (2001). Kosova - një histori e shkurtër, Prishtinë.

Matoshi, H. (2012). Hapësira etnike e kulturore shqiptare dhe Kisha Ortodokse Serbe, Shkup, Prishtinë, Tiranë.

Melqi, H. (1994). Opoja dhe Gora, Prishtinë.

Osi, M. (1996). Prizren drevni grad, utvrgjenja i njegova najneposrednija sella Jabllanica i Pousko, Prizren.

Panov, B. (1985). "Srednovekovna Makedonija”, Skopje.

Qafleshi, M. (2011). Opoja dhe Gora ndër shekuj, Prishtinë.

Qafleshi, M. (2014). Goranët dhe identiteti i tyre, Gjurmime albanologjike, nr. 43/2014, Prishtinë; Instituti Albanologjik -

\footnotetext{
${ }^{40}$ Feja, kultura dhe tradita ndër Shqiptarët, (1995), Prishtinë, pg .553.

${ }^{41}$ Enciklpodija likovnih umetnosti 2, Zagraeb, MCMLXII, pg. 155.

${ }^{42}$ Institute for Protection of Monuments of Cultural Heritage - Prizren Region.
} 
Prishtinë.

Shuteriq, D. (1980). Shënime mbi herezinë në Shqipëri, Studime historike"2, Tiranë.

Vickers, M. (2004). Midis serbëve dhe shqiptarëve, Tiranë.

\section{Monography}

Monography of the south Kosovo region, An EU funded project managed by the European Union Office in Kosovë Implemented by: Arbeiter - Samariter - Bund ASB, Prizren 2012.

Monography, Feja, kultura dhe tradita ndër Shqiptarët, Prishtinë, 1995.

\section{Enciklpoditë}

Enciklpodija likovnih umetnosti 2, Zagraeb, MCMLXII, pg. 155.

\section{Institute}

Institute for Protection of Monuments of Cultural Heritage - Prizren Region.

Internet

http://www.letersia.fajtori.com/Historia/Timari në shekullin XVI.

\section{Copyrights}

Copyright for this articleis retained by the author(s), with first publication rights granted to the journal.

This is an open-access article distributed under the terms and conditions of the CreativeCommons Attribution license (http://creativecommons.org/licenses/by/4.0/). 